\title{
The impact of National Macro-Environment Exogenous Variables on Airport Efficiency
}

\begin{abstract}
Our paper tests the extent to which airport efficiency is affected by national macro-environmental factors. The literature on airport performance measurement is extensive but has tended to focus mainly on estimating the effects on efficiency from what are mostly endogenous variables. We undertake a two-stage analysis of 59 international airports observations in the Europe and Asia-Pacific regions. The first stage involves the use of Data Envelopment Analysis (DEA) to measure the efficiency of these airports. This is followed by a second stage, where we use a Truncated Regression model that incorporates the Simar and Wilson bootstrapping technique to test the extent to which a set of macroenvironmental factors affect airport efficiency. Results reveal that a state's air transport sector output, institutional quality and robustness, the macro-economic environment, safety and security, and human development, all have a significant influence on the performance of airports. The result of this study fills the gap in the literature related to the non-discretionary variables affecting the performance of airports. It also suggests that policymakers and airport managers consider the identified factors when benchmarking airports.
\end{abstract}

\section{Keywords}

Airports efficiency; DEA method; Truncated Regression; Tobit Regression; macro-environmental factors; exogenous factors 


\section{Introduction}

The science and practice of airport performance measurement has evolved from the earliest phases of the sector's commercialisation in the 1970s through to the era of privatisation in the late 1990s and beyond. The first contribution came from Doganis \& Thompson (1973) and their analysis of the economic and financial performance of the UK airport industry. This and subsequent contributions developed what became known as the partial performance measurement framework, which was built around the derivation of ratios from selected combinations of inputs and outputs (Graham, 2018). The partial performance framework is still being applied in contemporary times but much more extensively in airport management practice, where it is perceived as having a particularly useful and practical application (ACI, 2012). However, the partial performance framework is limited in its ability to provide a more aggregated measure of efficiency because metrics are derived from selected combinations of inputs and outputs. For instance, factor substitution between, for example, labour and capital cannot be detected or diagnosed under the partial performance framework.

Since the late 1990s, there has, however, been a steady and growing interest in the development of more sophisticated multi-dimensional techniques that can overcome those limitations inherent in the partial performance framework. Some examples are the average approaches such as Total Factor Productivity (TFP) and Ordinary Least Squares (OLS), and frontier approaches such as Data Envelopment Analysis (DEA) and Stochastic Frontier Analysis (SFA). A review of the extensive body of literature on airport performance measurement shows that $78 \%$ of contributions have used nonparametric approaches, and of these, around 80\% have adopted DEA methods.

Contributions to the extensive literature on airport performance estimation using DEA will have typically estimated and compared the overall efficiency of individual airports in a given sample. In all of these instances, the efficiencies are determined by a relationship that exists between the airport's inputs and outputs and the sources of efficiency or inefficiency are all assumed to be endogenous to an airport's production system. However, there has been a minimal amount of research on the potential relationship that exists between exogenous factors and airport efficiency. Few papers have considered the effect of macro-environmental factors such as the level of economic development and location. Hooper (2002) and Chaouk et al. (2019) argue that the successes of airports, especially those that have been privatised, were to a large extent due to the effects of exogenous factors such as the presence of a well-developed, mature and stable institutional and regulatory framework coupled with a minimal level of political risk. This argument suggests that airport success in terms of performance or efficiency can be due to the effects of not only endogenous variables but those factors that are outside of managerial control that encompass sets of national macro-environmental factors; this hypothesis has yet to be thoroughly tested.

Therefore, this paper aims to fill in the gap in the literature related to whether macro-environmental factors do indeed have an influence on airport performance, and to identify the significant ones. This is done by conducting a test, using a two-stage approach involving the use of DEA and truncated regression with the Simar and Wilson bootstrapping technique on a sample of 59 airport observations in the Europe and Asia Pacific regions. Potentially our paper can be of value to governments, civil 
aviation authorities and regulators suggesting that they should consider the macro-environmental context in the airport benchmarking.

This paper is structured as follows. Section 2 provides a brief literature review on airport efficiency estimation. Section 3 describes the DEA model used to estimate the efficiency of the airports in the sample, the inputs and outputs used, and the empirical results. A second-stage regression is undertaken in Section 4, and our paper concludes with a final section which reflects on our key findings and provides recommendations for future policy.

\section{Literature Review}

Non-parametric efficiency estimation was initially used in the study of industrial organisational performance in the 1970s. However, it was not until the late 1990s that we are able to find examples of its application to the study of airport efficiency (Forsyth, 2007; Gillen and Lall, 1997). Since then, there have been more than 80 contributions to the literature on airport performance estimation and benchmarking.

Liebert and Niemeier (2013) provided an extensive literature survey which included 59 contributions on airport benchmarking papers published between 1997 and 2010. There are a further 34 contributions covering the years from 2013 to 2018. The methodological approaches fall into either one of two quantitative approaches: One-dimensional and multi-dimensional approach. The one-dimensional approach is resembled by Partial Performance measures (PP). On the other hand, the multi-dimensional methodologies can be based on either average approaches such as the index-based Total Factor Productivity (TFP) and the parametric Ordinary Least Squares (OLS), or on frontier approaches such as the parametric Stochastic Frontier Analysis (SFA) and the non-parametric Data Envelopment Analysis (DEA). More than $75 \%$ of the previous contributions have used the Frontier Approaches, and more than $80 \%$ of them have adopted DEA.

In the literature, several contributions comparing the performance of airports across countries at a global level have been published. Oum, Adler and Yu (2006) used VFP on 116 airports covering the period 2001 to 2003 and found that airports in the United States and Australia were more efficient compared to those in Asia and Europe. In contrast, a DEA analysis of 20 major airports in the years 2001 and 2002 showed that airports in Europe and the United States out-performed those in Asia and Australia (Lin and Hong, 2006). Both these contributions challenge the conclusions reached by Graham and Holvad (2000), who demonstrated that Australian airports achieved a superior level of performance compared to those in Europe through applying a DEA method on 25 European and 12 Australian Airports using data from 1992 and 1993. They also contradict with Abbott and Wu (2002), who concluded using DEA analysis on 24 international airports from 1992 and 1993 that Australian Airports outperform the US and European Airports.

There are some examples in the literature that have sought to identify the sources of efficiency variation between airports, or in other words, the sources of inefficiency using a second-stage regression. This approach has often involved the use of a non-parametric approach like DEA followed by a second- 
stage censored Tobit regression to identify the factors affecting airport efficiency as demonstrated by Abbott and Wu (2002), Barros and Sampaio (2004), Chi-Lok and Zhang (2009), Fragoudaki and Giokas (2016), and Gillen and Lall (1997). Other papers have used a truncated regression coupled with a bootstrapping technique (Barros, 2008a; Barros and Dieke, 2008; Merkert and Mangia, 2014; Örkcü et al., 2016; Tsui et al., 2014).

However, most of the factors examined by these contributions, especially those which included samples of airports representing different regions, are based around the fact that efficiency or inefficiency stems from factors that are endogenous. They are related directly to the airport physical characteristics, managerial strategies and governance structures. For example, Barros and Dieke (2008) and Abbott (2015) estimated the effect of airport size on airport performance. Barros and Dieke (2008), Chi-Lok and Zhang (2009), Gutiérrez and Lozano (2016), Örkcü et al. (2016), Tsui, Gilbey and Balli (2014), and Zou et al. (2015) have included airport hub status as one of the dummy variables. Another factor which has been used in many studies is traffic structure ${ }^{1}$ (e.g. Örkcü et al., 2016; Oum, Yan and Yu, 2008; Tovar and Martín-Cejas, 2009; Ülkü, 2015; Wing Chow and Fung, 2009). Other factors like noise strategy - Gillen and Lall (1997), service quality - Liu (2016) and Oum, Yu and Fu (2003), runway utilisation - Adler and Liebert (2014) and Zou et al. (2015), and congestion - Oum, Zhang and Zhang (2004), are all examples of endogenous factors that have been tested in the literature.

There have been several attempts to estimate the effect of ownership on the performance of airports. Some studies, using DEA, found no relationship between airport efficiency and type of ownership (e.g. Ahn and Min, 2014; Holvad and Graham, 2004; Lin and Hong, 2006; Oum, Yu and Fu, 2003; Parker, 1999). Similar conclusions were reached by Vasigh and Gorjidooz (2006) using Total Factor Productivity. Other studies concluded that privately-owned airports outperform the publically-owned ones, such as Barros and Dieke (2007) and Tsui, Gilbey and Balli (2014) using DEA. On the contrary, Gutiérrez and Lozano (2016) found, using DEA, that publically-owned airports achieve better operational efficiency than the privately-owned airports.

Most previous contributions that have adopted second-stage regression use endogenous independent variables. However, some have used variables that are beyond the control of airport management and outside of the airport industry itself. For example, Randrianarisoa et al. (2015) tested the effects of state-level corruption on the performance of the airports. Barros \& Sampaio (2004), Chi-Lok \& Zhang (2009), and Ülkü (2015) considered the effects of the population as an exogenous factor. However, we have not been able to find previous literature that has attempted to assess the effects of national macro-environmental factors on airport performance. An approach centred on exogenous effects could provide both an improved and informed understanding of why there is a variation on the level of airport efficiency between countries. A recent exploratory contribution by Chaouk, Pagliari, \& Miyoshi (2019) that sought to assess the effects of privatisation on the operational and financial performance of Medina Airport, argued that cultural dimensions, human resources strategies, administrative governance issues, and the socio-political environment were all factors that affected the airport's performance following privatisation.

${ }^{1}$ Traffic structure is the composition of airport traffic between international, domestic, general aviation etc. 
The identification of the factors which resemble the country level macro-environment starts with looking at the national competitiveness measurements. The definition of national competitiveness is the capability of a state to efficiently use its various resources, whether they are natural, human, or financial. McFetridge (1995)states that higher productivity and quality of life is usually achieved when there is a higher level of competitiveness. Therefore, national competitiveness has become a crucial policy aim for policymakers and researchers as they can use its indicators to estimate, analyse, and compare national performances.

Qualitative frameworks developed within the strategic management literature offer a particularly intuitive and convenient context within which it would be possible to develop a set of macroenvironmental factors. PEST analysis was initially developed by Aguilar (1967) to understand the effects of exogenous political, economic, social and technological influences on the development and performance of organisations. Fifield and Gilligan (2000) build on PEST by constructing a PESTEL framework which incorporates legal and environmental dimensions.

Quantitatively, there are different approaches used in measuring the competitiveness of the nations. However, the most common approach which became of great interest to researchers is the one which measures the competitiveness of a considerable number of countries and ranks them respectively (Lall, 2001). In this approach, a system of indicators are measured and then merged into a single index. There are several organisations and institutes that publish their own national competitiveness reports, and the most common ones are:

- Global Competitiveness Report (GCR) by World Economic Forum (WEF)

- World Competitiveness Yearbook (WCY) by Institute for Management Development (IMD)

- National Competitiveness Research Report (NCR) by Institute of Industrial Policy Studies (IPS)

- International Location Ranking (ILR) by Bertelsmann Foundation

WEF-GCR has been considered by policymakers as a consistent and reliable source for national macroenvironmental indicators. In addition, WEF, an autonomous not-for-profit foundation, is a pioneer in publishing competitiveness reports. The GCRs have been published on an annual basis starting the year 1996, and throughout the years, there has been a dramatic increase in the number of countries included in the report coupled with continuous development in the competitiveness index measuring methodology.

The GCR provides indices for 12 dimensions which collectively define a state's national competitiveness. The dimensions are: Institutions (INS), Infrastructure (INF), Macroeconomic environment (ME), Health and primary education (HPE), Higher education and training (HET), Goods market efficiency (GME), Labour market efficiency (LME), Financial market development (FMD), Technological readiness (TR), Market size (MS), Business Sophistication (BS), and Innovation (INNOV). The definitions of the dimensions are provided in the appendix. Each dimension is an aggregate of a set of indicators, and the aggregation of the dimensions provides a score for each country called the Global Competitiveness Index (GCI). A total of 114 indicators make up the 12 dimensions of the GCR. In their latest methodology to compute the GCI, the WEF obtains the scores of 78 indicators using an Executive Opinion Survey completed by thousands of business leaders. The 
remaining are obtained from renowned international bodies, including the International Monetary Fund (IMF), the United Nations, and the World Health Organisation (WEF, 2015a). A unified 1-to-7 scale is applied to the score of each indicator to simplify the aggregation process. Then, the score of each dimension of the GCR is calculated by dividing the aggregate scores of its respective indicators over the total number of indicators. After that, the score of each pillar is multiplied by a specific weight that is assigned according to the sub-index of the dimension and the stage of the development of the country ${ }^{2}$.

Itani, O'Connell and Mason (2014) made one of the first attempts in the literature to test the impact of macro-environmental factors on the air transport sector quantitatively. In their study, the 12 WEFGCR pillars in addition to four additional macro-environmental factors (population count, surface area, and political and security stability) were tested against four national air transport outputs (total passengers, aviation contribution to GDP, aviation contribution to employment, and air connectivity) using structural equation modelling (SEM) to identify the macro-environmental factors that influence the outputs of the air transport sector.

Therefore our paper takes this initial exploratory contribution and tests using a broader international sample of airports as to whether national macro-environment factors do indeed have an effect on airport efficiency and to identify the significant factors.

\section{Estimation of airport efficiency using Data Envelopment Analysis (DEA)}

\subsection{The Model}

Charnes, Cooper and Rhodes (1978), through the development of original constant returns to scale model (CRS), pioneered the use of DEA methods in measuring the efficiency of industrial organisations. Their work builds on more fundamental contributions to the economic theory of efficiency developed by Debreu (1951) and Farrell (1957). Later, Banker, Charnes and Cooper (1984) extended the original CRS model to include a variable returns to scale (VRS) model. The first application of DEA to the airport industry was the contribution by Gillen and Lall (1997).

DEA is used to estimate the efficiency of a sample of Decision Making Units (DMUs). Each DMU operates a system of production that uses multiple inputs and outputs. Homogeneity in the selection of DMUs is essential, in that it is not possible to compare organisations from very different sectors of the economy. So in broad terms, DMUs should be undertaking similar activities and producing similar outputs (Dyson et al., 2001). The advantage of DEA is that it automatically builds a piecewise linear frontier which is determined by the efficient DMUs of the sample using a linear programming approach, so there is no requirement to pre-specify a functional form for the production or cost frontier (Liebert and Niemeier, 2013). DMUs' efficiency is measured relative to the frontier, which is itself determined by the most efficient DMUs in the sample.

\footnotetext{
${ }^{2}$ For more information on the $\mathrm{GCl}$ methodology, refer to WEF (2015a)
} 
There are two types of DEA model: input-oriented and output-oriented. An input-oriented DEA model involves, for each DMU, establishing the most minimal level of inputs while maintaining the same level of outputs. However, an output-oriented DEA model maximises the outputs produced by each DMU while maintaining the inputs at the same level. The choice between adopting an input or outputoriented model is to a large extent, driven by the nature of the industry that is being studied. According to the literature, the most suitable model that has been used in the airport sector is the output-oriented model. This is related to the fact that airports, by their very nature, are capital-intensive assets, where costs are mostly fixed, infrastructure sunk and capital investment irreversible (Liebert and Niemeier, 2013).

Regarding returns to scale, three basic models exist: Constant Return to Scale (CRS), Variable Return to Scale (VRS), and the additive model. In the CRS model, it is assumed that for a given change in the inputs, the outputs will change by the same proportion. In addition, the CRS model measures the overall efficiency of every DMU. However, the VRS model assumes that there could be decreasing, constant, and increasing returns to scale, and it allows for the measurement of the pure technical efficiency of a DMU. In the literature, the majority of studies that used DEA assumed VRS because of the presence of different airport sizes in the dataset (Liebert and Niemeier, 2013). Therefore, in our paper, we use an output-orientated VRS model as there is variation in airport size across our sample and it is assumed that the proportions of the input variables are constant providing scope for efficiency improvement.

The basic CCR model measures the efficiency of a DMU by calculating the maximum of the ratio of the sum of the weighted outputs to the sum of the weighted inputs, as shown in equation (1):

$H_{o}=\operatorname{Max}_{u_{r}, v_{i}} \frac{\sum_{r=1}^{m} u_{r} y_{r o}}{\sum_{i=1}^{n} v_{i} x_{i o}}$

Subject to:

$\frac{\sum_{r=1}^{m} u_{r} y_{r j}}{\sum_{i=1}^{n} v_{i} x_{i j}} \leq 1 \quad j=1,2,3, \ldots, n$.

Where:

$u_{r} v_{i} \geq 0 ; \quad r=1,2,3, \ldots, m ; \quad i=1,2,3, \ldots, n$.

$H_{o}$ represents the DEA efficiency index of an airport $y_{r j}$, the positive known output of the $j^{\text {th }}$ DMU and $x_{i j}$ the positive known input of the $j^{\text {th }}$ DMU and $u_{r}, v_{i}$ represent the weights of the input and output variables to be calculated by the model.

The DEA-BCC model is shown in equation (2):

$\theta=\max \varphi+\varepsilon\left[\sum_{r=1}^{m} s_{r o}^{+}+\sum_{i=1}^{n} s_{i o}^{-}\right]$

Subject to:

$\sum_{r=1}^{m} y_{r j} \lambda_{j}-s_{r o}^{+}=\varphi y_{r o} \quad r=1,2,3, \ldots, m$; 
$\sum_{i=1}^{n} x_{i j} \lambda_{j}+s_{i o}^{-}=x_{i o} \quad i=1,2,3, \ldots, n$;

$\sum_{r=1}^{m} \lambda_{j}=1 ; \quad \lambda_{j} \geq 0 ; \quad j=1,2,3, \ldots, l$.

Where $\theta$ represents the DEA efficiency index of an airport $\varepsilon$ the constant (greater than zero), $s_{r o}^{+}$: the output slack of the DMU, $s_{i o}^{-}$the input slack of the DMU and $\lambda_{j}$ is the dual variable or the scalar vector related with each DMU.

According to Cooper, Seiford, \& Tone (2006), a DMU is considered to be efficient when $\theta$ is equal to one and its input and output slacks are equal to zero $\left(s_{r o}^{+}=0, s_{i o}^{-}=0\right)$. In this case, the output of the DMU falls on the production frontier. However, when $\theta$ is below one, then the DMU is producing below the production frontier and hence the DMU is technically considered to be inefficient.

\subsection{Data}

Our original sample included data from 120 international airports drawn from a wide range of geographic locations representing a spectrum of different ownership models. However, we were required to eliminate 61 airports due to issues relating to both the quality and availability of consistent data. Therefore, our final sample included a combination of 59 European and Asia-Pacific airports collected from the ATRS World Airports Benchmarking Database for the years 2009 and 2015 (ATRS, 2010, 2016). There is no specific reason for collecting airports data for years 2009 and 2015 except for the availability of their databases to the researchers. Table 1 shows the characteristics of the airports in the sample.

Table 1: $\quad$ Airports Sample

\begin{tabular}{llcc}
\hline Airport & State & 2009 data & 2015 data \\
\hline Amsterdam Schiphol International Airport & Netherlands & Yes & Yes \\
Athens International Airport & Greece & Yes & Yes
\end{tabular}




\begin{tabular}{|c|c|c|c|}
\hline Auckland International Airport & New Zealand & Yes & \\
\hline Bai Yun Airport & China & & Yes \\
\hline Bandaranaike International Airport & Sri Lanka & & Yes \\
\hline Bratislava Milan Rastislav Stefanik Airport & Slovakia & & Yes \\
\hline Brussels International Airport & Belgium & Yes & \\
\hline Budapest Ferihegy International Airport & Hungary & Yes & \\
\hline Christchurch International Airport & New Zealand & & Yes \\
\hline Copenhagen Kastrup International Airport & Denmark & Yes & Yes \\
\hline Dublin International Airport & Ireland & Yes & Yes \\
\hline Frankfurt Main International Airport & Germany & Yes & Yes \\
\hline Geneva Cointrin International Airport & Switzerland & Yes & Yes \\
\hline Guangzhou Bai Yun Airport & China & Yes & \\
\hline Haneda Airport & Japan & & Yes \\
\hline Helsinki Vantaa International Airport & Finland & Yes & Yes \\
\hline Incheon International Airport & South Korea & & Yes \\
\hline Istanbul Ataturk International Airport & Turkey & Yes & Yes \\
\hline Kansai International Airport & Japan & Yes & Yes \\
\hline Keflavik International Airport & Iceland & Yes & Yes \\
\hline Kuala Lumpur International Airport & Malaysia & Yes & \\
\hline Lennart Meri Tallinn Airport & Estonia & & Yes \\
\hline Lisbon Portela Airport & Portugal & Yes & Yes \\
\hline Ljubljana Jože Pučnik Airport & Slovenia & & Yes \\
\hline London Heathrow International Airport & UK & Yes & Yes \\
\hline Madrid Barajas International Airport & Spain & Yes & Yes \\
\hline Manchester International Airport & UK & Yes & Yes \\
\hline Melbourne Airport & Australia & & Yes \\
\hline Munich International Airport & Germany & Yes & Yes \\
\hline Oslo Airport & Norway & Yes & \\
\hline Paris Charles de Gaulle Airport & France & Yes & Yes \\
\hline Rome Leonardo Da Vinci/Fiumicino Airport & Italy & Yes & Yes \\
\hline Singapore Changi International Airport & Singapore & Yes & \\
\hline Stockholm Arlanda International Airport & Sweden & Yes & \\
\hline Suvarnabhumi Airport & Thailand & Yes & \\
\hline Sydney Kingsford Smith International Airport & Australia & Yes & \\
\hline Tokyo International Airport & Japan & Yes & \\
\hline Vienna International Airport & Austria & Yes & Yes \\
\hline Warsaw Chopin Airport & Poland & Yes & \\
\hline Zurich International Airport & Switzerland & Yes & Yes \\
\hline
\end{tabular}

To estimate the efficiency of each airport, we select a set of input and output variables. The selection criterion was based on the most common variables found to be used in the literature.

For each airport, we use four output variables: the number of passengers (PAX), number of air traffic movements (ATM), the volume of cargo (in metric tonnes), and non-aeronautical revenue (in \$US). As far as the input variables are concerned, we include the number of runways, number of gates, terminal area (in meters squared), and the number of employees (Table 2). Although non-aeronautical revenue was excluded in some studies such as Fernandes and Pacheco (2002), Pels et al. (2001), ChiLok and Zhang (2009), and Barros (2009), other studies claimed that excluding it would cause bias in 
the results as the airport should be viewed as a technology that conducts both aeronautical and nonaeronautical activities such as Barros and Dieke (2007), Oum, et al. (2006b), Oum et al. (2008), and Pacheco et al. (2006).

Table 2: $\quad$ Summary of input and output variables included in the sample.

\begin{tabular}{|c|c|c|c|c|c|c|c|}
\hline Variables & Mean & Std. Dev. & Min & Max & Skewness & Kurtosis & Data source \\
\hline \multicolumn{8}{|l|}{ Inputs } \\
\hline Runways & 2.54 & 1.039 & 1 & 6 & 1.314 & 2.559 & ATRS $(2010,2016)$ \\
\hline Gates & 89.29 & 58.56 & 12 & 226 & 0.923 & -0.014 & ATRS $(2010,2016)$ \\
\hline Terminal Area $\left(\mathrm{m}^{2}\right)$ & $349,059.4$ & 326660 & 13,000 & $1,523,886$ & 1.641 & 2.748 & ATRS $(2010,2016)$ \\
\hline Total number of employees & $2,431.92$ & $3,238.71$ & 177 & 17,441 & 3.169 & 1.805 & ATRS $(2010,2016)$ \\
\hline \multicolumn{8}{|l|}{ Outputs } \\
\hline Total Passengers (PAX) & $1.53 \mathrm{E}+07$ & $2.26 \mathrm{E}+07$ & 1,658 & $7.50 \mathrm{E}+07$ & 1.363 & 0.635 & ATRS $(2010,2016)$ \\
\hline Air Traffic Movements (ATM) & $2.53 \mathrm{E}+05$ & $1.33 \mathrm{E}+05$ & 24,622 & $5.18 \mathrm{E}+05$ & 0.245 & -0.840 & ATRS $(2010,2016)$ \\
\hline Total Cargo (Tonnes) & $5.97 \mathrm{E}+05$ & $6.82 \mathrm{E}+05$ & 10,140 & $2.49 \mathrm{E}+06$ & 1.272 & 0.401 & ATRS $(2010,2016)$ \\
\hline Total non-aeronautical revenue (US\$) & $4.41 \mathrm{E}+08$ & $4.36 \mathrm{E}+08$ & $9.80 \mathrm{E}+06$ & $1.79 \mathrm{E}+09$ & 1.579 & 1.832 & ATRS $(2010,2016)$ \\
\hline
\end{tabular}

An important consideration regarding the robustness of DEA estimation, which directly affects the number of efficient DMUs, is the ratio of the number of observations to the total number of inputs and outputs used. Seiford and Thrall (1990) and Pedraja-Chaparro, Salinas-Jiménez and Smith (1999) show that the discriminatory power of DEA models weakens in cases where the ratio of the number of observations to the total number of inputs and outputs used is low. This problem has been addressed in the literature. For example, Golany and Roll (1989) recommend that the number of observations should be at least twice more than the total number of inputs and outputs used in the model. Both Bankers (1989) and Cooper, Seiford and Tone (2007) suggest that the total number of observations should be three times more than the total number of inputs and outputs in the model. Our model achieves a ratio of 7.4, which is well within the minimum range recommended above, as we have used 59 statistical observations with 4 variables measuring outputs and 4 representing inputs.

\subsection{Empirical Results}

The results, shown in Table 3 below, were obtained through the use of PIM Ver. 3.2 software, for both constant returns to scale (CRS) and variable returns to scale (VRS) models. Efficiency scores for each airport DMU range from 0 to 1 with 1 being an efficient DMU while any scoring less than one indicates a degree of inefficiency. 32 airports out of 56 are technically efficient under the assumption of CRS while there are 42 technically efficient airports when we use the VRS model. It is also clear from Table 3 that all technically efficient airports under the CRS assumption are also technically efficient under the VRS assumption.

Table 3: $\quad$ Efficiency scores of airports included in the sample

\begin{tabular}{llllcr}
\hline DMU & Code & Year & Airport Name & Efficiency (CRS) & Efficiency (VRS) \\
\hline AP001 & AMS & 2009 & Amsterdam Schiphol International Airport & 1.000 & 1.000 \\
AP002 & ATH & 2009 & Athens International Airport & 1.000 & 1.000 \\
AP003 & AKL & 2009 & Auckland International Airport & 1.000 & 1.000 \\
AP004 & BRU & 2009 & Brussels International Airport & 0.963 & 0.986
\end{tabular}




\begin{tabular}{|c|c|c|c|c|c|}
\hline AP005 & BUD & 2009 & Budapest Ferihegy International Airport & 0.732 & 0.741 \\
\hline AP006 & $\mathrm{CPH}$ & 2009 & Copenhagen Kastrup International Airport & 1.000 & 1.000 \\
\hline AP007 & DUB & 2009 & Dublin International Airport & 1.000 & 1.000 \\
\hline AP008 & MUC & 2009 & Frankfurt Main International Airport & 1.000 & 1.000 \\
\hline AP009 & GVA & 2009 & Geneva Cointrin International Airport & 1.000 & 1.000 \\
\hline AP010 & CAN & 2009 & Guangzhou Bai Yun Airport & 0.996 & 1.000 \\
\hline AP011 & HEL & 2009 & Helsinki Vantaa International Airport & 0.804 & 0.822 \\
\hline AP012 & IST & 2009 & Istanbul Ataturk International Airport & 0.654 & 0.799 \\
\hline AP013 & KIX & 2009 & Kansai International Airport & 1.000 & 1.000 \\
\hline AP014 & KEF & 2009 & Keflavik International Airport & 0.555 & 1.000 \\
\hline AP015 & KUL & 2009 & Kuala Lumpur International Airport & 0.591 & 0.638 \\
\hline AP016 & LIS & 2009 & Lisbon Portela Airport & 0.573 & 0.614 \\
\hline AP017 & LHR & 2009 & London Heathrow International Airport & 1.000 & 1.000 \\
\hline AP018 & MAD & 2009 & Madrid Barajas International Airport & 0.763 & 0.991 \\
\hline AP019 & MAN & 2009 & Manchester International Airport & 1.000 & 1.000 \\
\hline AP020 & FRA & 2009 & Munich International Airport & 1.000 & 1.000 \\
\hline AP021 & OSL & 2009 & Oslo Airport & 1.000 & 1.000 \\
\hline AP022 & CDG & 2009 & Paris Charles de Gaulle International Airport & 1.000 & 1.000 \\
\hline AP023 & FCO & 2009 & Rome Leonardo Da Vinci/Fiumicino Airport & 0.741 & 0.814 \\
\hline AP024 & SIN & 2009 & Singapore Changi International Airport & 0.815 & 1.000 \\
\hline AP025 & ARN & 2009 & Stockholm Arlanda International Airport & 0.866 & 0.893 \\
\hline AP026 & BKK & 2009 & Suvarnabhumi Airport & 0.849 & 0.891 \\
\hline AP027 & SYD & 2009 & Sydney Kingsford Smith International Airport & 1.000 & 1.000 \\
\hline AP028 & HND & 2009 & Tokyo International Airport & 1.000 & 1.000 \\
\hline AP029 & VIE & 2009 & Vienna International Airport & 1.000 & 1.000 \\
\hline AP030 & WAW & 2009 & Warsaw Chopin Airport & 0.378 & 0.519 \\
\hline AP031 & ZRH & 2009 & Zurich International Airport & 0.921 & 1.000 \\
\hline AP032 & AMS & 2015 & Amsterdam Schiphol International Airport & 1.000 & 1.000 \\
\hline AP033 & ATH & 2015 & Athens International Airport & 1.000 & 1.000 \\
\hline AP034 & $\mathrm{CMB}$ & 2015 & Bandaranaike International Airport & 0.785 & 1.000 \\
\hline AP035 & BTS & 2015 & Bratislava Milan Rastislav Stefanik Airport & 0.330 & 0.400 \\
\hline AP036 & $\mathrm{CHC}$ & 2015 & Christchurch International Airport & 0.696 & 1.000 \\
\hline AP037 & $\mathrm{CPH}$ & 2015 & Copenhagen Airport Kastrup & 0.788 & 0.804 \\
\hline AP038 & DUB & 2015 & Dublin International Airport & 1.000 & 1.000 \\
\hline AP039 & FRA & 2015 & Frankfurt Airport & 1.000 & 1.000 \\
\hline AP040 & GVA & 2015 & Geneva Cointrin International Airport & 1.000 & 1.000 \\
\hline AP041 & CAN & 2015 & Guangzhou Bai Yun Airport & 1.000 & 1.000 \\
\hline AP042 & HND & 2015 & Haneda Airport & 1.000 & 1.000 \\
\hline AP043 & HEL & 2015 & Helsinki Vantaa Airport & 1.000 & 1.000 \\
\hline AP044 & $\mathrm{ICN}$ & 2015 & Incheon International Airport & 0.837 & 1.000 \\
\hline AP045 & IST & 2015 & Istanbul Atatürk Airport & 1.000 & 1.000 \\
\hline AP046 & KIX & 2015 & Kansai International Airport & 1.000 & 1.000 \\
\hline AP047 & $\mathrm{KEF}$ & 2015 & Keflavik International Airport & 0.633 & 0.954 \\
\hline AP048 & TLL & 2015 & Lennart Meri Tallinn Airport & 0.490 & 0.630 \\
\hline AP049 & LIS & 2015 & Lisbon Portela Airport & 0.745 & 1.000 \\
\hline AP050 & LJU & 2015 & Ljubljana Jože Pučnik Airport & 0.750 & 1.000 \\
\hline AP051 & LHR & 2015 & London Heathrow Airport & 1.000 & 1.000 \\
\hline AP052 & MAD & 2015 & Madrid Barajas Airport & 0.725 & 0.835 \\
\hline AP053 & MAN & 2015 & Manchester International Airport & 0.992 & 1.000 \\
\hline
\end{tabular}




\begin{tabular}{llllll} 
AP054 & MEL & 2015 & Melbourne Airport & 1.000 & 1.000 \\
AP055 & MUC & 2015 & Munich Airport & 1.000 & 1.000 \\
AP056 & CDG & 2015 & Paris Charles de Gaulle Airport & 1.000 & 1.000 \\
AP057 & FCO & 2015 & Rome Leonardo Da Vinci/Fiumicino Airport & 0.803 & 0.814 \\
AP058 & VIE & 2015 & Vienna International Airport & 1.000 & 1.000 \\
AP059 & ZRH & 2015 & Zurich International Airport & 1.000 & 1.000 \\
\hline
\end{tabular}

\section{Identifying the effect of macro-environmental factors on airport efficiency through truncated regression with Simar and Wilson bootstrapping technique and Tobit regression}

\subsection{The Models}

To identify the exogenous factors that are significantly affecting the efficiency of the airports, previous airport performance studies have conducted various second-stage analyses including simple ordinary least squares (OLS), Tobit regression, and Truncated regression (Barros, 2008b). The majority of studies before 2007 employed Tobit regression until Simar and Wilson indicated through their study that it is not appropriate to use this method. Simar \& Wilson (2007) argued that a proper approach to address the obscure sequential correlation which could affect the two-stage analysis is to conduct truncated regression coupled with bootstrapping technique. Other studies, such as Banker \& Natarajan (2008) and Hoff (2007) concluded that OLS, maximum likelihood estimation, or Tobit regression, are appropriate approaches to apply when using DEA efficiency estimates. In addition, Latruffe et al. (2004) and Bravo-Ureta et al. (2007) argued that Tobit regression is the best option since the first-stage DEA analysis gives scores between zero and one. Therefore, there is an open debate among econometric researchers on the most appropriate second-stage regression model. In this study, we employed truncated regression with bootstrapping technique. Similar to Kan Tsui et al. (2014) and Merkert \& Hensher (2011), we also conducted Tobit regression to check for robustness of the results obtained from the bootstrapped truncated regression.

In the truncated regression with Simar and Wilson bootstrapping technique, the efficiency scores obtained from the first-stage DEA analysis are regressed against the factors that are expected to have an effect on the DEA efficiency scores (see Simar \& Wilson, 2007).

The initial first-order estimation of the unknown true relationship can be written, as shown in Equation (3):

$\theta_{j}=\alpha+z_{j} \beta+\varepsilon_{j} ; j=1,2,3, \ldots, n$.

Where;

$\theta_{j}:$ DEA efficiency score of the $\mathrm{j}^{\text {th }}$ DMU

$\alpha$ : Constant

$z_{j}$ : Vector of the variables that are thought to affect the DEA efficiency scores of the DMUs

$\beta$ : Vector of coefficients 


\section{$\varepsilon_{j}:$ Error term}

In Simar and Wilson bootstrapping approach, there is a limitation to distribution of the error term $\varepsilon_{j}$ according to the condition $\varepsilon_{j} \geq 1-\alpha-z_{i} \beta$. Therefore, the distribution of $\varepsilon_{j}$ becomes $\varepsilon_{j} \sim \operatorname{iidN}\left(0, \sigma_{\varepsilon}^{2}\right)$. In addition, $\theta_{j}^{*}$ (which resembles the DEA efficiency score after applying the Simar and Wilson bootstrapping technique), replaces the true and unobserved dependent variable $\theta_{j}$ of Equation (3). So, the Simar and Wilson model specification is as shown in Equation (4).

$\theta_{j}^{*}=\alpha+z_{j} \beta+\varepsilon_{j} ; j=1,2,3, \ldots, n ; \varepsilon_{j} \sim \operatorname{iidN}\left(0, \sigma_{\varepsilon}^{2}\right)$

The Tobit model falls into the censored regression category. It is used when the dependent variable is bounded from below, above, or both (Tobin, 1958). It is also considered as an alternative to Ordinary Least squares (OLS) regression. The observed dependent variable $Y_{i}$ is related to a latent variable $Y_{i}^{*}$ as shown below:

$$
Y_{i}=\left\{\begin{array}{ccc}
Y_{i}^{*} & \text { if } Y_{i}^{*}>0 \\
0 & \text { if } Y_{i}^{*} \leq 0
\end{array}\right.
$$

In general, we use the following equation (5), which is similar to that used by Carlucci, Cirà and Coccorese (2018):

$Y_{i}^{*}=\beta X_{i}+\varepsilon_{i} \quad i=1, \ldots, N$

Where $N$ represents the number of observations (in our case DMUs) and $X_{i}$ represents a vector of independent variables. A vector of unknown coefficients to be estimated is represented by $\beta$. The error term $\varepsilon_{i}$ is assumed to be independent and normally distributed error term.

$\varepsilon_{i} \sim N\left(0, \sigma^{2}\right) \beta X_{i}$

\subsection{Data}

The dependent variable in our model is represented by the efficiency score of each airport obtained from the DEA model presented in Section 3.

Our empirical strategy for the bootstrapped truncated regression and the Tobit model estimation is based on selecting independent variables that can represent a set of relevant macro-economic factors. The choice of the quantitative form led us to consider indices produced by the World Economic Forum (WEF) in their annual Global competitiveness Report (GCR). We choose the WEF national competitiveness factors which appear to be the most consistent and reliable source for accessing statelevel macro-environmental indicators (Itani, O'Connell and Mason, 2015; Lall, 2001). We use independent variables that represent the 12 dimensions of the WEF-GCR. The values of each dimension are state-level, so we apply these to the respective airport(s) listed in Table 3 for the years 2009 and 2015. 
We also include an independent variable, developed by Itani, O'Connell and Mason (2015) representing each state's Air Transport Output (ATO), which is an index that represents the performance of the national air transport industry. This index is an aggregation of the following four state-level indicators: total traffic growth, aviation's contribution to gross domestic product (GDP) and employment, and air service connectivity. The 2009 data for the ATO variable was obtained from Itani (2015), while we use the same model to estimate values for 2015.

Finally, four additional independent variables were included in order to cover other dimensions of national macro-environmental effects. These were: Global Peace Index (SS) (measures the degree of safety and security), a Corruption Perception Index (CPI) (measures levels of corruption in a respective state's public sector), Human Development Index (HDI) (measures population health and capabilities), and Travel and Tourism Index (TT) (measures the attractiveness of a state for the purposes of investing in its travel and tourism sector). Data used for all the independent variables was collected from WEF Global Competitiveness (WEF-GCR), WEF-Travel \& Tourism (WEF-TT), Institute for Economics and Peace (IEP), Transparency International (TI), and United Nations Development Program (UNDP) 2009 and 2015 reports for each country relative to its airport in the sample (Table 4).

We apply a multicollinearity test to all independent variables used in the Tobit regression model using the Variance Inflation Factor (VIF). This measures the scale of the increase in the variance of a given coefficient estimate that is due to the presence of collinearity with other tested variables (Akinwande, Dikko and Samson, 2015). There is disagreement in the literature regarding what is considered to be an acceptable VIF value threshold. Kline (1998) and Hair et al. (2009) argue in support of VIF tolerance thresholds that are between 5 and 10. Table 5 below indicates the presence of multicollinearity across all selected variables with differing degrees of intensity.

Table 4: $\quad$ Summary of independent variables included in the sample

\begin{tabular}{llccccc}
\hline Variables & Definition & Mean & Std. Dev. & Min & Max & Data Source \\
\hline ATO & Air Transport Output & 0.876 & 0.241 & 0.007 & 1.0 & $($ Itani, 2015) \\
INS & Institutions & 5.0 & 0.8 & 3.4 & 6.1 & WEF (2009, 2015) \\
INF & Infrastructure & 5.4 & 0.8 & 2.9 & 6.6 & WEF (2009, 2015) \\
ME & Macro-economic environment & 5.0 & 0.8 & 3.3 & 6.6 & WEF (2009, 2015)
\end{tabular}




\begin{tabular}{|c|c|c|c|c|c|c|}
\hline HPE & Health and primary education & 6.2 & 0.3 & 5.3 & 6.9 & WEF $(2009,2015)$ \\
\hline HET & Higher education and training & 5.2 & 0.5 & 3.9 & 6.1 & WEF $(2009,2015)$ \\
\hline GME & Goods market efficiency & 4.9 & 0.4 & 4.1 & 5.8 & WEF $(2009,2015)$ \\
\hline LME & Labour market efficiency & 4.7 & 0.6 & 3.4 & 5.9 & WEF $(2009,2015)$ \\
\hline FMD & Financial market development & 4.6 & 0.7 & 2.8 & 5.9 & WEF $(2009,2015)$ \\
\hline TR & Technological readiness & 5.3 & 0.8 & 3.3 & 6.3 & WEF $(2009,2015)$ \\
\hline MS & Market size & 4.9 & 0.9 & 2.4 & 7.0 & WEF $(2009,2015)$ \\
\hline $\mathrm{BS}$ & Business sophistication & 5.0 & 0.6 & 3.8 & 5.9 & WEF $(2009,2015)$ \\
\hline INNOV & Innovation & 4.5 & 0.8 & 3.1 & 5.8 & WEF $(2009,2015)$ \\
\hline SS & Safety and Security & 4.8 & 0.8 & 2.9 & 6.1 & IEP $(2009,2015)$ \\
\hline CPI & Corruption perception & 7.1 & 1.8 & 3.4 & 9.4 & TI $(2009,2015)$ \\
\hline HDI & Human Development & 4.1 & 0.4 & 2.5 & 4.7 & UNDP $(2009,2015)$ \\
\hline $\mathrm{TT}$ & Travel and tourism & 4.9 & 0.4 & 3.8 & 5.7 & WEF (2009b, 2015b) \\
\hline
\end{tabular}

\section{Table 5: $\quad$ Multicollinearity test 1}

\begin{tabular}{|c|c|c|c|}
\hline Variables & Definition & Tolerance & VIF \\
\hline ATO & Air Transport Output & 0.376 & 2.66 \\
\hline INS & Institutions & 0.024 & $11.51^{* *}$ \\
\hline INF & Infrastructure & 0.087 & $41.97^{* *}$ \\
\hline $\mathrm{ME}$ & Macro-economic environment & 0.125 & $7.97^{*}$ \\
\hline HPE & Health and primary education & 0.099 & $10.11^{* *}$ \\
\hline HET & Higher education and training & 0.045 & $22.17^{* *}$ \\
\hline GME & Goods market efficiency & 0.111 & $9.04^{*}$ \\
\hline LME & Labour market efficiency & 0.065 & $15.50^{* *}$ \\
\hline FMD & Financial market development & 0.083 & $12.10^{* *}$ \\
\hline $\mathrm{TR}$ & Technological readiness & 0.041 & $24.25^{* *}$ \\
\hline MS & Market size & 0.046 & $21.56^{* *}$ \\
\hline BS & Business sophistication & 0.038 & $26.66^{* *}$ \\
\hline INNOV & Innovation & 0.023 & $42.78^{* *}$ \\
\hline SS & Safety and Security & 0.208 & 4.82 \\
\hline CPI & Corruption perception & 0.037 & $27.20^{* *}$ \\
\hline HDI & Human Development & 0.143 & $7.01^{*}$ \\
\hline TT & Travel and tourism & 0.164 & $6.08^{*}$ \\
\hline
\end{tabular}

${ }^{*} \mathrm{VIF}>5 .{ }^{* *} \mathrm{VIF}>10$ 
Table 5 shows that several variables are associated with high levels of multicollinearity. The model's robustness can be improved by removing those variables that are associated with particularly VIF values. We remove those variables with the highest VIF values through several iterations until an optimum set is achieved where levels of multicollinearity have been minimised. Our final set of independent variables, each with VIF values that are less than 5, are presented in Table 6 below. This process yields five variables: Air Transport Output (ATO), Institutions (INS), Macro-economic environment (ME), Global Peace Index (SS) and Human Development Index (HDI).

\section{Table 6: $\quad$ Final model with limited multicollinearity}

\begin{tabular}{llcc}
\hline Variables & Definition & Tolerance & VIF \\
\hline ATO & Air Transport Output & 0.59 & 1.69 \\
INS & Institutions & 0.31 & 3.23 \\
ME & Macro-economic environment & 0.79 & 1.27 \\
SS & Safety and Security & 0.38 & 2.64 \\
HDI & Human Development & 0.65 & 1.54 \\
\hline
\end{tabular}

Therefore, our final truncated regression to be calculated through the bootstrapped process in the second-stage analysis is shown in equation $(6)^{3}$ :

$\theta_{i, t}{ }^{*}=\beta_{0}+\beta_{1} A T O_{i, t}+\beta_{2} I N S_{i, t}+\beta_{3} M E_{i, t}+\beta_{4} S S_{i, t}+\beta_{5} H D I_{i, t}+\varepsilon_{i, t}$

And our final random effect Tobit regression model can be expressed as in equation (7):

$Y_{i}=\beta_{0}+\beta_{1} A T O_{i}+\beta_{2} I N S_{i}+\beta_{3} M E_{i}+\beta_{4} S S_{i}+\beta_{5} H D I_{i}+\varepsilon_{i}$

\subsection{Empirical Results}

In Table 7, the marginal effect of each independent variable on airport efficiency according to bootstrapped truncated regression and Tobit regression is represented by their respective P-value. We report P-value results at the $95 \%$ confidence level, so an independent variable with a value lower than 0.05 is considered to be statistically significant.

Table 7: $\quad$ Significance levels (P-values) of independent variables to Airport

Efficiency by both bootstrapped truncated regression Tobit regression

\begin{tabular}{llcccc}
\hline \multirow{2}{*}{ Variables } & Definition & \multicolumn{2}{c}{ Truncated regression with bootstrapping } & \multicolumn{2}{c}{ Random effect Tobit regression } \\
\cline { 3 - 6 } & & Coefficient & P-value & Coefficient & P-value \\
\hline \multirow{2}{*}{ ATO } & Air Transport Output & 0.586 & $0.000^{* *}$ & 0.472 & $0.000^{* *}$ \\
ISN & Institutions & 0.104 & $0.027^{* *}$ & 0.018 & $0.043^{* *}$
\end{tabular}

\footnotetext{
${ }^{3}$ For more details, see Simar \& Wilson (2007)
} 


\begin{tabular}{|c|c|c|c|c|c|}
\hline ME & Macro-economic Environment & 0.091 & $0.013 * *$ & 0.025 & $0.012 * *$ \\
\hline SS & Safety and Security & -0.392 & $0.004 * *$ & -0.092 & $0.026 * *$ \\
\hline HDI & Human Development & 0.780 & $0.009 * *$ & 0.196 & $0.038 * *$ \\
\hline Constant & - & -0.761 & 0.093 & 0.253 & 0.147 \\
\hline & Log-likelihood & \multirow{2}{*}{\multicolumn{2}{|c|}{$\begin{array}{c}180.187 \\
59\end{array}$}} & \multirow{2}{*}{\multicolumn{2}{|c|}{$\begin{array}{c}230.438 \\
59\end{array}$}} \\
\hline & Observations & & & & \\
\hline
\end{tabular}
${ }^{* *}$ Significant at a $95 \%$ level of confidence. The results of truncated regression with bootstrapping technique of
Simar and Wilson (2007) were obtained from 5000 bootstrapping iterations.

The results of the truncated regression with bootstrapping technique show some interesting findings with regards to the impact of macro-environmental factors on airport efficiency. The results show that all the independent variables that were included in the regression are statistically significant. All the independent variables except Safety and Security recorded a positive coefficient. This means that the efficiency of the airport would increase with the increase in the value of any of these variables.

The negative coefficient recorded by Safety and Security variable demonstrates the different scaling system adopted by the Institute for Economics and Peace as shown in the Appendix, where the data on Safety and Security are provided according to 1 to 5 score index with score 1 being the most peaceful. In other words, the lower Safety and Security score, the higher the real level of peace and safety in the respective country. Therefore, the negative coefficient recorded by the Safety and Security variable means that the efficiency of the airport decreases when the real level of safety and security in the country languishes. This is verified by real-life examples such as the terrorist attacks in Turkey in the year 2016, including the terrorist attack at Ataturk International Airport. As a result of these events, the level of Safety and Security factor in Turkey in 2016 became higher. In the same year, a 4\% drop in the Turkish aviation market and a $2 \%$ drop in the number of passengers at Ataturk International Airport were recorded. This resulted in a hit to the earnings of the airports, wherein Ataturk International Airport, a 9\% decrease in the EBITDA compared to 2015 was achieved (TAV, 2016). This is not only due to the drop in the number of passengers, but because of the drop in the commercial revenues as a result of the extensive security measures that increased processing times of passengers at the check-in desks, immigration, and security screening.

The results of the truncated regression show that the Air Transport Sector's Output, which resembles the level of maturity of the civil aviation authority, regulations, and policies of the country is the significant variable. This is reasonable due to the relationship that exists between the airport activity and the civil aviation regulatory framework. This result is also in line with Chaouk, Pagliari, \& Miyoshi (2019) and Holder et al. (2008) who emphasized on the importance of the existence of a full autonomous civil aviation authority that follows robust and advanced regulatory framework on the performance of the airport.

Human Development variable, which demonstrates the standards of living dimensions of the population in the country including the level of health and education, significantly affects the efficiency of the airport according to the results of the bootstrapped truncated regression. This finding also agrees with the arguments provided by Chaouk, Pagliari, \& Miyoshi (2019) who discussed the significance of having adequate, well-educated and trained, competent, and good human resources for the successful and efficient performance of the airport. This finding also agrees with Pabedinskaite 
and Akstinaite (2014) and Sutia et al. (2013), who concluded that the human development factor significantly influences the performance of the airport.

Institutions variable is also shown to be significant to the efficiency of the airport. By definition, the higher the score of the institutions index, the higher the quality of the public and private institutions, the more robust and advance administrative and legal framework, and thus the lower level of corruption among the institutions of the country. Therefore, logically, when the airport operates in an environment that has robust institutional arrangements, this would help the airport operators in their mission to achieve higher efficiency levels. This finding is also in line with Chaouk, Pagliari, \& Miyoshi (2019), who argued that poorly developed institutional arrangements and regulatory mechanism of a country negatively affects the performance of the airport.

Finally, the efficiency of the airport is also shown to be significantly affected by the Macro-economic Environment variable. Although this term is broad and resembles the stability of the macroenvironment in a country as defined in Appendix, it was also found to be significantly affecting the total number of air passengers and the aviation contribution to employment by a study conducted by Itani, O'Connell and Mason (2014). Therefore, it is also reasonable that the macro-economic environment significantly affects the performance of the airports.

Table 7 also shows that all the five national macro-environmental variables are also significant to the efficiency of the airport according to the results of the Tobit regression, thus validating the results of bootstrapped truncated regression.

\section{Conclusions}

In this paper, we applied a two-stage approach to identify which national macro-environmental factors influence airport efficiency. In the first step, we estimated the efficiency of 59 international airports in the years 2009 and 2015 using both CRS and VRS output-oriented DEA models. Following on from this, we tested the extent to which airport efficiency is affected by 17 national macro-environmental factors. After testing for multicollinearity, we eliminated 12 factors. The remaining 5 factors were the country's Air Transport Output, Institutions, Macro-economic Environment, Safety and Security, and Human Development. Truncated regression with Simar and Wilson bootstrapping technique was used to estimate the extent to which the efficiency of the airports as the dependant factor is affected by the 5 national macro-environmental factors as independent factors. Truncated regression showed that all these five independent factors were significantly influencing the performance of the airports. Tobit regression was executed to test for robustness, and the results were very similar to the ones obtained by the bootstrapped truncated regression.

This result is significant as it proves that there are macro-environmental factors, outside the boundaries of airports, contributing to the performance of the airports and thus explaining the differences in the efficiencies of the airports around the world, thus filling the gap in the literature as stated in section 2 of this paper. This finding suggests that airport efficiency is not only affected by factors related to the airport physical characteristics, management strategies, governance structures, or other individual factors. The efficiency of the airport is influenced by the combination of five national macro- 
environmental factors, namely the air transport output, institutions, macro-economic environment, human development, and safety and security. The importance of this finding lies in the fact that it can give governments, civil aviation authorities, and airports' management an overall picture of what influences the performance of their airport on the national level. In addition, this finding brings the attention to the airport managers, operators, and consultants to consider the macro-environmental context of the countries respective to the airports when conducting an airport benchmarking to compare the performance of their airport to other airports. It suggests that to better compare the performance of an airport to others, the particular airport should be benchmarked against airports located in countries that have similar scores of the five identified national macro-environmental factors.

The major limitation of this study is the availability of data. Therefore, would a more extensive sample dataset of airports be available, preferably a dataset which includes airports from other regions such as Africa, Latin America, and the Middle East, the results of the DEA and the second stage regression would give a better picture on the relationship between airport performance and national macroenvironmental factors.

Finally, an attempt to qualitatively identify the national macro-environmental factors that significantly affect the performance of the airports using interviews would be interesting research that could provide a contrast to the results of the quantitative approach of this study. 


\section{Appendix}

\begin{tabular}{|c|c|c|c|}
\hline Variable & Description & Type of data & Source \\
\hline Institutions & $\begin{array}{l}\text { Measurement of the quality of public and private institutions of a country which depends on the administrative and } \\
\text { legal framework within which individuals, businesses, and governments interact. }\end{array}$ & 1 to 7 score index & (WEF, 2009a, 2015a) \\
\hline Infrastructure & $\begin{array}{l}\text { Measurement of the quality of the general infrastructure including the systems that ensure effective functioning of the } \\
\text { country's economy such as modes of transportation (high-quality roads, railroads, sea ports, and airports), } \\
\text { telecommunications network, electricity supplies, and sewage and water systems. }\end{array}$ & 1 to 7 score index & (WEF, 2009a, 2015a) \\
\hline $\begin{array}{l}\text { Macroeconomic } \\
\text { environment }\end{array}$ & $\begin{array}{l}\text { Measurement of the stability of the macro-environment through examining government budget balance, government } \\
\text { past debts, control of inflation, national rate of savings and the spread of the rate of interests. }\end{array}$ & 1 to 7 score index & (WEF, 2009a, 2015a) \\
\hline $\begin{array}{l}\text { Health and primary } \\
\text { education }\end{array}$ & $\begin{array}{l}\text { Measurement of the health services quality of the country, the level of health of the population and the cost of health } \\
\text { on overall economy. In addition, it includes the measurement of the quality of the basic education received by the } \\
\text { population such as: education expenditure, quality of primary education and education enrolment rates. }\end{array}$ & 1 to 7 score index & (WEF, 2009a, 2015a) \\
\hline $\begin{array}{l}\text { Higher education and } \\
\text { training }\end{array}$ & $\begin{array}{c}\text { Measurement of the secondary and tertiary enrolment rates in addition to the quality of education systems and } \\
\text { training (examining expenditure on higher education, quality of management schools, Internet access in schools and } \\
\text { universities and the availability of research and training institutions). Staff training is also taken into consideration in } \\
\text { this measurement. }\end{array}$ & 1 to 7 score index & (WEF, 2009a, 2015a) \\
\hline Goods market efficiency & $\begin{array}{l}\text { Measurement of the capability of a country to generate the right proportion of products and services according to its } \\
\text { specific supply-and-demand settings. It takes into consideration domestic and foreign competition as well as the } \\
\text { degree of customer orientation and buyer sophistication. }\end{array}$ & 1 to 7 score index & (WEF, 2009a, 2015a) \\
\hline Labour market efficiency & $\begin{array}{l}\text { Measurement of the flexibility and efficiency of the labour market in terms of rigidity of employment, redundancy } \\
\text { costs, effect of taxation, pay versus productivity rates and the reliance on professional management. It takes into } \\
\text { consideration the ability of the labour market to shift employees from one economic activity to another in a rapid and } \\
\text { low cost process, the presence of incentives and meritocracy at the workplace, and the gender equity in the business } \\
\text { environment. }\end{array}$ & 1 to 7 score index & (WEF, 2009a, 2015a) \\
\hline $\begin{array}{c}\text { Financial market } \\
\text { development }\end{array}$ & $\begin{array}{l}\text { Measurement of the productivity and efficiency of the financial by examining the appropriate distribution of national } \\
\text { resources and foreign investments to achieve most productive economic outcomes. }\end{array}$ & 1 to 7 score index & (WEF, 2009a, 2015a) \\
\hline Technological readiness & $\begin{array}{l}\text { Measurement the nimbleness with which an economy implements existing technologies to improve the productivity of } \\
\text { its industries. It emphasises on the nation's capacity to influence information and communication technologies in daily } \\
\text { production processes for increased efficiency and innovation. }\end{array}$ & 1 to 7 score index & (WEF, 2009a, 2015a) \\
\hline
\end{tabular}




\begin{tabular}{|c|c|c|c|}
\hline Market size & Measurement of the total volume of a certain market in terms of the sizes of the domestic market and foreign market. & 1 to 7 score index & (WEF, 2009a, 2015a) \\
\hline Business sophistication & $\begin{array}{l}\text { Measurement of the quality of a country's overall business networks (by examining the quantity and quality of local } \\
\text { suppliers and the extent of their interaction) and the quality of individual firms' operations and strategies. These two } \\
\text { factors are mostly important for countries at an advanced stage of development. }\end{array}$ & 1 to 7 score index & (WEF, 2009a, 2015a) \\
\hline Innovation & $\begin{array}{l}\text { Measurement of the capacity for innovation in a certain economy by examining the degree of investment in research } \\
\text { and development (R\&D), especially by the private sector; the presence of high-quality scientific research institutions } \\
\text { that can generate the basic knowledge needed to build the new technologies; the existence of extensive collaboration } \\
\text { in research and technological developments between universities and industry; and the degree of protection of } \\
\text { intellectual property }\end{array}$ & 1 to 7 score index & (WEF, 2009a, 2015a) \\
\hline $\begin{array}{l}\text { Travel and tourism } \\
\text { competitiveness }\end{array}$ & $\begin{array}{l}\text { Measurement of the factors and policies that urge-on and ease the growth of travel and tourism (T\&T) sector in a } \\
\text { certain country. It emphasises on the T\&T regulatory framework, business environment and infrastructure, in addition } \\
\text { to human, cultural and natural resources. }\end{array}$ & 1 to 6 score index & (WEF, 2009b, 2015b) \\
\hline $\begin{array}{l}\text { Safety and security } \\
\text { stability }\end{array}$ & $\begin{array}{l}\text { Measurement of the level of safety and security in a certain country. It considers internal and external factors } \\
\text { extending from the level of military expenditure to the country's relations with neighbouring countries. It also } \\
\text { considers the level of democracy and respect for human rights. }\end{array}$ & $\begin{array}{l}1 \text { to } 5 \text { score index ( } 5 \\
\text { being least peaceful) }\end{array}$ & $($ IEP, 2009, 2015) \\
\hline Corruption perception & $\begin{array}{l}\text { Measurement of the level of corruption in the public sector of a certain country through the perception of the experts } \\
\text { and business people. }\end{array}$ & $\begin{array}{l}1 \text { to } 100 \text { score index } \\
\text { with } 100 \text { being least } \\
\text { corrupted }\end{array}$ & (TI, 2009, 2015) \\
\hline Human development & $\begin{array}{l}\text { Measurement of the average achievement in key dimensions of human development including health dimension } \\
\text { (measured by the life expectancy at birth), education dimension (measured by the mean of schooling years for adults } \\
\text { above } 25 \text { years old and expected schooling years for children of school entering age), and the standard of living } \\
\text { dimension (measured by the gross national income per capita) }\end{array}$ & $\begin{array}{l}0 \text { to } 1 \text { index score with } \\
1 \text { being very high } \\
\text { human development }\end{array}$ & (UNDP, 2009, 2015) \\
\hline Air Transport Output & $\begin{array}{l}\text { The measurement of the air transport sector's performance of a certain country taking into consideration the total air } \\
\text { passenger traffic, aviation contribution to GDP ad employment, level of air connectivity, air liberalisation, and airport } \\
\text { ownership. }\end{array}$ & $\begin{array}{l}0 \text { to } 1 \text { index score with } \\
1 \text { being the most } \\
\text { efficient }\end{array}$ & (Itani, 2015) \\
\hline
\end{tabular}




\section{References}

Abbott, M. (2015) 'Reform and efficiency of New Zealand's airports', Utilities Policy, 36, pp. 1-9.

Abbott, M. and Wu, S. (2002) 'Total factor productivity and efficiency of Australian airports', Australian Economic Review, 35(3), pp. 244-260.

ACI (2012) Guide to Airport Performance Measures.Wyman, O. (ed.) Montreal, Canada: Airports Council International.

Adler, N. and Liebert, V. (2014) 'Joint impact of competition, ownership form and economic regulation on airport performance and pricing', Transportation Research Part A: Policy and Practice, 64 Elsevier Ltd, pp. 92-109.

Aguilar, F.J. (1967) Scanning the Business Environment. 1st edn. New York: MacMillan Co.

Ahn, Y.H. and Min, H. (2014) 'Evaluating the multi-period operating efficiency of international airports using data envelopment analysis and the Malmquist productivity index', Journal of Air Transport Management, 39 Elsevier Ltd, pp. 12-22.

Akinwande, M.O., Dikko, H.G. and Samson, A. (2015) 'Variance Inflation Factor: As a Condition for the Inclusion of Suppressor Variable(s) in Regression Analysis', Open Journal of Statistics, 05(07), pp. 754-767.

ATRS (2010) Global Airport Benchmarking Database 2009. Vancouver.

ATRS (2016) Global Airport Benchmarking Database 2015. Vancouver.

Banker, R. and Natarajan, R. (2008) 'Evaluating Contextual Variables Affecting Productivity Using Data Envelopment Analysis', Operations Research, 56(1), pp. 48-58.

Banker, R.D., Charnes, A. and Cooper, W.W. (1984) 'Some Models for Estimating Technical and Scale Inefficiencies in Data Envelopment Analysis', Management Science, 30(9), pp. 1078-1092.

Bankers, R.D. (1989) 'An introduction to data envelopment analysis with some of its models and their uses', Journal of governmental and non-profit accounting, (5), pp. 125-163.

Barros, C.P. (2008a) 'Technical efficiency of UK airports', Journal of Air Transport Management, 14(4), pp. 175-178.

Barros, C.P. (2008b) 'Airports in Argentina: Technical efficiency in the context of an economic crisis', Journal of Air Transport Management, 14(6) Elsevier Ltd, pp. 315-319.

Barros, C.P. and Dieke, P.U.C. (2008) 'Measuring the economic efficiency of airports: A SimarWilson methodology analysis', Transportation Research Part E: Logistics and Transportation Review, 44(6), pp. 1039-1051.

Barros, C.P. and Dieke, P.U.C. (2007) 'Performance evaluation of Italian airports: A data envelopment analysis', Journal of Air Transport Management, 13(4), pp. 184-191. 
Barros, C.P. and Sampaio, A. (2004) 'TECHNICAL AND ALLOCATIVE EFFICIENCY IN

AIRPORTS', International Journal of Transport Economics, 31(3), pp. 335-377.

Bravo-Ureta, B.E., Solís, D., Moreira López, V.H., Maripani, J.F., Thiam, A. and Rivas, T. (2007)

'Technical efficiency in farming: a meta-regression analysis', Journal of Productivity Analysis, 27(1), pp. 57-72.

Carlucci, F., Cirà, A. and Coccorese, P. (2018) 'Measuring and Explaining Airport Efficiency and Sustainability: Evidence from Italy’, Sustainability, 10(2), p. 400.

Chaouk, M., Pagliari, R. and Miyoshi, C. (2019) 'A critical review of airport privatisation in the Kingdom of Saudi Arabia: Case study of Medina Airport', Case Studies on Transport Policy

Charnes, A., Cooper, W.W. and Rhodes, E. (1978) 'Measuring the efficiency of decision making units', European Journal of Operational Research, 2(6), pp. 429-444.

Chi-Lok, A.Y. and Zhang, A. (2009) 'Effects of competition and policy changes on Chinese airport productivity: An empirical investigation', Journal of Air Transport Management, 15(4) Elsevier Ltd, pp. 166-174.

Cooper, W.W., Seiford, L.M. and Tone, K. (2006) Introduction to Data Envelopment Analysis and Its Uses. Boston: Kluwer Academic Publishers.

Cooper, W.W., Seiford, L.M. and Tone, K. (2007) Data Envelopment Analysis: A Comprehensive Text with Models, Applications, References and DEA-Solver Software. 2nd edn. Boston, MA: Springer US.

Debreu, G. (1951) ‘The Coefficient of Resource Utilization', Econometrica, 19(3), p. 273.

Doganis, R. and Thompson, M.A. (1973) The economics of british airport. London.

Dyson, R.G., Allen, R., Camanho, A.S., Podinovski, V. V., Sarrico, C.S. and Shale, E.A. (2001) 'Pitfalls and protocols in DEA', European Journal of Operational Research, 132(2), pp. 245-259.

Farrell, M.J. (1957) 'The Measurement of Productive Efficiency', Journal of the Royal Statistical Society. Series A (General), 120(3), p. 253.

Fernandes, E. and Pacheco, R.R. (2002) 'Efficient use of airport capacity', Transportation Research Part A: Policy and Practice, 36(3), pp. 225-238.

Fifield, P. and Gilligan, C. (2000) Strategic Marketing Management: Planning and Control. Oxford: Butterworth Heinemann.

Forsyth, P. (2007) 'Models of Airport Performance', in Hensher, D. (ed.) Handbook of Transport Modelling. Oxford: Elsevier Ltd, pp. 715-727.

Fragoudaki, A. and Giokas, D. (2016) 'Airport performance in a tourism receiving country: Evidence from Greece’, Journal of Air Transport Management, 52, pp. 80-89. 
Gillen, D. and Lall, A. (1997) 'Developing measures of airport productivity and performance: An application of data envelopment analysis', Transportation Research Part E: Logistics and Transportation Review, 33(4), pp. 261-273.

Golany, B. and Roll, Y. (1989) 'An application procedure for DEA', Omega, 17(3), pp. 237-250.

Graham, A. (2018) 'Airport economics and finance', in Halpern, N. and Graham, A. (eds.) The Routledge Companion to Air Transport Management. 1st edn. London: Routledge, p. 17.

Graham, A. and Holvad, T. (2000) EFFICIENCY MEASUREMENT FOR AIRPORTS. Oxford.

Gutiérrez, E. and Lozano, S. (2016) 'Efficiency assessment and output maximization possibilities of European small and medium sized airports', Research in Transportation Economics, 56, pp. 3-14.

Hair, J.F., Black, W.C., Babin, B.J. and Anderson, R.E. (2009) Multivariate Data Analysis. 7th edn. Upper Saddle River: Prentice Hall.

Hoff, A. (2007) 'Second stage DEA: Comparison of approaches for modelling the DEA score', European Journal of Operational Research, 181(1), pp. 425-435.

Holder, S., Bulman, E., Webb, H., Carter, S. and Eynde, O. Vanden (2008) The Impact of International Air Transport Liberalisation on Employment.

Holvad, T. and Graham, A. (2004) 'Efficiency measurement for UK Airports: An application of data envelopment analysis', The Empirical Economics Letters, 3(1), pp. 31-39.

Hooper, P. (2002) 'Privatization of airports in Asia', Journal of Air Transport Management, 8(5), pp. 289-300.

IEP (2009) Global Peace Index 2009. Sydney.

IEP (2015) Global Peace Index 2015. Sydney.

Itani, N. (2015) POLICY DEVELOPMENT FRAMEWORK FOR AVIATION STRATEGIC PLANNING IN DEVELOPING COUNTRIES. Cranfield University.

Itani, N., O’Connell, J.F. and Mason, K. (2014) 'A macro-environment approach to civil aviation strategic planning', Transport Policy, 33 Elsevier, pp. 125-135.

Itani, N., O’Connell, J.F. and Mason, K. (2015) 'Towards realizing best-in-class civil aviation strategy scenarios', Transport Policy, 43 Elsevier, pp. 42-54.

Kline, R.B. (1998) Principles and Practice of Structural Equation Modeling. 1st edn. New York: The Guilford Press.

Lall, S. (2001) 'Competitiveness Indices and Developing Countries: An Economic Evaluation of the Global Competitiveness Report’, World Development, 29(9), pp. 1501-1525.

Latruffe, L., Balcombe, K., Davidova, S. and Zawalinska, K. (2004) 'Determinants of technical 
efficiency of crop and livestock farms in Poland', Applied Economics, 36(12), pp. 1255-1263.

Liebert, V. and Niemeier, H.M. (2013) 'A survey of empirical research on the productivity and efficiency measurement of airports', Journal of Transport Economics and Policy, 47(PART2), pp. 157-189.

Lin, L.C. and Hong, C.H. (2006) 'Operational performance evaluation of international major airports: An application of data envelopment analysis', Journal of Air Transport Management, 12(6), pp. 342-351.

Liu, D. (2016) 'Measuring aeronautical service efficiency and commercial service efficiency of East Asia airport companies: An application of Network Data Envelopment Analysis', Journal of Air Transport Management, 52 Elsevier Ltd, pp. 11-22.

McFetridge, D.G. (1995) Competitiveness : concepts and measures. Ottawa: Industry Canada, 5.

Merkert, R. and Hensher, D.A. (2011) 'The impact of strategic management and fleet planning on airline efficiency - A random effects Tobit model based on DEA efficiency scores', Transportation Research Part A: Policy and Practice, 45(7), pp. 686-695.

Merkert, R. and Mangia, L. (2014) 'Efficiency of Italian and Norwegian airports: A matter of management or of the level of competition in remote regions?', Transportation Research Part A: Policy and Practice, 62 Elsevier Ltd, pp. 30-38.

Örkcü, H.H., Balikçi, C., Dogan, M.I. and Genç, A. (2016) 'An evaluation of the operational efficiency of turkish airports using data envelopment analysis and the Malmquist productivity index: 2009-2014 case', Transport Policy, 48, pp. 92-104.

Oum, T.H., Adler, N. and Yu, C. (2006) 'Privatization, corporatization, ownership forms and their effects on the performance of the world's major airports', Journal of Air Transport Management, 12(3), pp. 109-121.

Oum, T.H., Yan, J. and Yu, C. (2008) 'Ownership forms matter for airport efficiency: A stochastic frontier investigation of worldwide airports', Journal of Urban Economics, 64(2), pp. 422-435.

Oum, T.H., Yu, C. and Fu, X. (2003) 'A comparative analysis of productivity performance of the world's major airports: Summary report of the ATRS global airport benchmarking research report 2002', Journal of Air Transport Management, 9(5), pp. 285-297.

Oum, T.H., Zhang, A. and Zhang, Y. (2004) 'Alternative Forms of Economic Regulation and their Effciency Implications for Airports', Journal of Transport Economics and Policy, 38(2), pp. 217246.

Pabedinskaitè, A. and Akstinaite, V. (2014) 'Evaluation of the Airport Service Quality', Procedia Social and Behavioral Sciences, 110, pp. 398-409.

Pacheco, R.R., Fernandes, E. and de Sequeira Santos, M.P. (2006) 'Management style and airport performance in Brazil', Journal of Air Transport Management, 12(6), pp. 324-330.

Parker, D. (1999) 'The Performance of BAA before and after Privatisation: A DEA Study', Journal 
of Transport Economics and Policy, 33(2), pp. 133-145.

Pedraja-Chaparro, F., Salinas-Jiménez, J. and Smith, P. (1999) 'On the quality of the data envelopment analysis model', Journal of the Operational Research Society, 50(6), pp. 636-644.

Pels, E., Nijkamp, P. and Rietveld, P. (2001) 'Relative efficiency of European airports', Transport Policy, 8(3), pp. 183-192.

Pestana Barros, C. (2009) 'The Measurement of Efficiency of UK Airports, Using a Stochastic Latent Class Frontier Model', Transport Reviews, 29(4), pp. 479-498.

Randrianarisoa, L.M., Bolduc, D., Choo, Y.Y., Oum, T.H. and Yan, J. (2015) 'Effects of corruption on efficiency of the European airports', Transportation Research Part A: Policy and Practice, 79, pp. 65-83.

Seiford, L.M. and Thrall, R.M. (1990) 'Recent developments in DEA: The mathematical programming approach to frontier analysis', Journal of Econometrics, 46(1-2) North-Holland, pp. 738. Available at: 10.1016/0304-4076(90)90045-U (Accessed: 28 November 2018).

Simar, L. and Wilson, P.W. (2007) 'Estimation and inference in two-stage, semi-parametric models of production processes', Journal of Econometrics, 136(1), pp. 31-64.

Sutia, S., Sudarma, M., Djumahir and Rofiaty (2013) 'The Influence of Human Capital Investment, Leadership and Strategic orientation on Airport Performance', International Journal of Business and Management Invention, 2(6), pp. 26-32.

TAV (2016) TAV Airports Annual Report 2016. Istanbul.

TI (2009) CORRUPTION PERCEPTIONS INDEX 2009. Berlin.

TI (2015) CORRUPTION PERCEPTIONS INDEX 2015. Berlin.

Tobin, J. (1958) 'Estimation of Relationships for Limited Dependent Variables', Econometrica, 26(1), p. 24.

Tovar, B. and Martín-Cejas, R.R. (2009) 'Are outsourcing and non-aeronautical revenues important drivers in the efficiency of Spanish airports?', Journal of Air Transport Management, 15(5), pp. 217-220.

Tsui, W.H.K., Balli, H.O., Gilbey, A. and Gow, H. (2014) 'Operational efficiency of Asia-Pacific airports', Journal of Air Transport Management, 40, pp. 16-24.

Tsui, W.H.K., Gilbey, A. and Balli, H.O. (2014) 'Estimating airport efficiency of New Zealand airports', Journal of Air Transport Management, 35, pp. 78-86.

Ülkü, T. (2015) 'A comparative efficiency analysis of Spanish and Turkish airports', Journal of Air Transport Management, 46, pp. 56-68.

UNDP (2009) Human Development Report 2009. Overcoming barriers: Human mobility and 
development.

UNDP (2015) Human Development Report 2015. Work for Human Development.

Vasigh, B. and Gorjidooz, J. (2006) 'Productivity analysis of public and private airports: a casual investigation', Journal of Air Transportation, 11(3), pp. 144-163.

WEF (2009a) The Global Competitiveness Report 2009. Geneva.

WEF (2015a) The Global Competitiveness Report 2015. Geneva.

WEF (2009b) The Travel \& Tourism Competitiveness Report 2009. Geneva.

WEF (2015b) The Travel \& Tourism Competitiveness Report 2015. Geneva.

Wing Chow, C.K. and Fung, M.K.Y. (2009) 'Efficiencies and scope economies of Chinese airports in moving passengers and cargo', Journal of Air Transport Management, 15(6) Elsevier Ltd, pp. 324-329.

Zou, B., Kafle, N., Chang, Y.T. and Park, K. (2015) 'US airport financial reform and its implications for airport efficiency: An exploratory investigation', Journal of Air Transport Management, 47, pp. 66-78. 
$2019-10-28$

The impact of national

macro-environment exogenous

variables on airport efficiency

\author{
Chaouk, Mohammed
}

Elsevier

Chaouk M, Pagliari R, Moxon R. (2020) The impact of national macro-environment exogenous variables on airport efficiency. Journal of Air Transport Management, Volume 82, January 2020, Article number 101740

httsp://doi.org/10.1016/j.jairtraman.2019.101740

Downloaded from Cranfield Library Services E-Repository 